Archives of Agriculture and Environmental Science

\title{
Determination of irrigation regime for hot pepper (Capsicum annum L.) in dry-land areas of Wag- Himra, North Eastern Amhara, Ethiopia
}

\author{
Aemro Wale ${ }^{*}$ and Gebrehana Girmay \\ Sekota Dry Land Agricultural Research Center, P.O. Box 62, Sekota, ETHIOPIA \\ *Corresponding author's E-mail: geberhanagirmay@gmail.com
}

\section{ARTICLE HISTORY}

Received: 16 February 2019

Revised received: 26 February 2019

Accepted: 03 March 2019

\section{Keywords}

Hot pepper (Capsicum annum L.)

Irrigation regime

Marketable yield

Wag-Himra

Water productivity

\begin{abstract}
A field experiment to evaluate CROPWAT model estimations was conducted during the year 2014 and 2015 on Ziqualla and Abergelle. This field experiment was therefore conducted to determine net irrigation requirements and irrigation schedules of hot pepper (Capsicum annum L.) using CROPWAT computer model and to validate using field trial. A split plot design with the main plot of water depth and subplot of irrigation frequency has been used. Three levels of water amount with (I1), (I2), and (I3) CROPWAT generated depth and three levels of irrigation frequency at (5), (7) and (9) days interval were used as a treatment. Additionally, one treatment farmer practice irrigation depth and interval has been used as a control. The experimental result showed that irrigation application of I1 CROPWAT generated depth at 5 days irrigation interval obtained a relatively higher and statistically significant marketable yield, water productivity on both Ziqualla and Abergelle. In terms of economic profitability, it was found that irrigation application I1 CROPWAT generated depth at 5 days irrigation interval had 7.7ton/ha and 6ton/ha economically yield advantageous associated that 12 CROPWAT generated depth with 7 days irrigation interval on Ziqualla and Abergelle, congruently. Considering the above results, irrigation application of I1 CROPWAT generated depth at 5 days interval was found economically feasible and recommended to improve crop and water productivity of the irrigation schemes by saving a significant amount of water for irrigating additional lands for hot pepper (C. annum) crop production both Ziqualla and Abergelle smallscale irrigation schemes.
\end{abstract}

(C)2019 Agriculture and Environmental Science Academy

Citation of this article: Wale, A. and Girmay, G. (2019). Determination of irrigation regime for hot pepper (Capsicum annum L.) in dry-land areas of Wag- Himra, North Eastern Amhara, Ethiopia. Archives of Agriculture and Environmental Science, 4(1): 101-108, https://dx.doi.org/10.26832/24566632.2019.0401016

\section{INTRODUCTION}

Hot pepper (Capsicum annum L.) is an important commercial crop, cultivated for vegetable, spice, and value-added processed products (Nalla et al., 2017). It originated from the American with their cultivars are now grown around the world because they are widely used as food and medicine (Mazourek et al., 2009). Peppers are one of the most susceptible horticultural crops to drought stress due to its broad range of transpiring leaf surface, high stomatal conductance (Alvino et al., 1994) and shallow root system (Kulkarni and Phalke, 2009, Liu et al., 2012). Pepper production accounts for $34 \%$ of the total spice produc- tion in the three regions of Ethiopia namely Amhara, Oromia and Southern Nations Nationalities and Peoples Regional States (Roukens et al., 2005). FAO, (2017) the report indicated that the estimated production of peppers in Ethiopia was 220,791ton from 97,712 ha in green form and 118,514 ton of dry pepper from an area of 300,000 ha.

Increase in population has led to an upsurge in the demand of food (pepper) and fiber which has also resulted in the adoption of irrigation to sustain plant growth (Delfine et al., 2015). As population rises and development calls for, the distributions of ground and surface water for domestic, agriculture and industrial sectors augmented; as a result, the pressure on water 
resources strengthens. The increasing stress on freshwater resources transported about by an ever-rising demand for water is of thoughtful concern (FAO, 2017). Notwithstanding the increase in water use by subdivisions other than agriculture, irrigation carries on to be the main water user on a worldwide. Irrigated agriculture consumes more than $70 \%$ of the water demanding from the rivers of the world and for the developing world; the proportion can reach $80 \%$ (FAO, 2017). The condition is no more different in Ethiopia. It has been obviously and noisily stated that if Ethiopia is to feed its ever-increasing population, lessen the risk of disasters caused by drought, and increase population density in the dry and thinly populated areas, incessant and extensive effort need to be made towards developing irrigated agriculture and intensifying agricultural production. Irrigation will, therefore, play a progressively important role now and in the upcoming years both to increase the agricultural yield from already refined land and to permit the cultivation of what is currently known as marginal or unusable land due to the moisture deficiency.

Water availability is the most limiting factor for crop production in the dry-land areas of Ziqualla and Abergelle. Moreover, lack of crop water requirement studies for major crops had been a challenge for appropriate utilization of scarce water resource in irrigated agriculture and it leads to low water use efficiency through improper irrigation scheduling. Determination of water requirement of the crop, appropriate irrigation scheduling can be designed, which can lead to improvements in the yield, income, and water saving (Bossie et al., 2009). To ensure the highest crop production with the least water use, it is important to know the water requirement of the crops (Tyagi et al., 2000). This improves the efficient and economic use of irrigation water. However, effective irrigation water management is possible only with regular monitoring of soil water and crop development conditions in the field, and with the forecasting of future crop water needs. Delaying in the irrigation until crop stress is evident, or using too little water, that can result in substantial yield loss of the crops. Applying too much water to the plot of land will cause to extra pumping costs, wasted water due to evaporation and runoff, and increased risk for leaching valuable agrichemicals below the rooting zone. Proper timing of irrigation water applications is therefore an important decision tool for a farm manager to meet the water needs of the crop, to prevent yield loss due to water stress, and for maximizing the irrigation water use efficiency which resulted in beneficial use and conservation of the scarce water resources, and minimize the leaching potential of nitrates (Valipour, 2015). Ziqualla and Abergelle woreda, small-scale irrigation scheme is typically applied on a monotonous basis without scheduling and inadequate management of irrigation water has been an important limiting factor to pepper production. Growers generally lack knowledge on features of soil-water-plant relationship and they apply water to the crop irrespective of the plant needs. They seem to relate irrigation occurrence to days after planting with fixed intervals and water amounts rather than to crop stage progress. The information of the proper irrigation time and scheduling, when to irrigate the crops and how much water to apply in irrigation, is essential to optimize crop production per unit water and for sustaining irrigated agriculture on permanent footing (Kirda, 2002). Therefore, this study was conducted with the objective of determining the net irrigation requirements and irrigation schedules of hot pepper (Capsicum annum L.) using CROPWAT computer model and to validate using a field trial.

\section{MATERIALS AND METHODS}

A field experiment was conducted during 2014 and 2015 in Ziqualla and Abergelle district, Wag Himra Administrative Zone of Amhara Region (Figure 1). The study sites are located at $1414332 \mathrm{~N}$ and $475070 \mathrm{E}$ at Ziqualla; $1425280 \mathrm{~N}$ and $495749 \mathrm{E}$ at Abergelle. The altitude of the study areas are $1465 \mathrm{~m}$ and $1260 \mathrm{~m}$ Ziqualla and Abergelle m.a.s.l., respectively. The sites are characterized by clay texture soils. The soil particle size distribution of clay, silt, and sand is $41.29 \%, 29.92 \%, 28.79 \%$ at Ziqualla and $41.3 \%, 26.7 \%, 32 \%$ at Abergelle, respectively. Field capacity and permanent wilting point of the sites are $32.92 \%$ and $19.03 \%$ for Ziqualla (Tsitsika small-scale irrigation scheme) and $32.51 \%$ and $16.28 \%$ for Abergelle (Bahir small-scale irrigation scheme).

\section{Experimental setup}

A field experiment to evaluate the CROPWAT model estimations was conducted during the 2014 and 2015. The experiment plot of $2.8 \mathrm{~m}$ by $3 \mathrm{~m}$ was used to test irrigation regimes. Hot pepper (Capsicum annum L. var. Marko fana) was selected as the test crop. The selected marko fana has a production cycle of 125 days including transplanting up to second harvesting with the initial crop growth stage of about 20 days, crop development stage of 35 days, mid-season stage of 50 days and late season stage of 20 days, which was derived from CROPWAT software. Plant spacing was set at $70 \mathrm{~cm}$ and $30 \mathrm{~cm}$ between rows and plants, respectively. Blanket recommended fertilizer rate of Dia Ammonium Phosphate $100 \mathrm{~kg} / \mathrm{ha}$ at transplanting and urea fertilizer of $100 \mathrm{~kg} / \mathrm{ha}$ at half transplanting and half 45 days was applied in both experimental sites. Both diseases and weed infestations were regularly monitored, and proper management action has been undertaken timely. Cutworms were observed during the early seedling establishments on the actual field, whereas Fusarium wilt was a problem at a vegetative and plant development stages. Karate and Mancozeb ( $3 \mathrm{~kg} / \mathrm{ha}$ ) were used to control the disease infestation which was practiced according to the label (EIAR, 2004).

CROPWAT optimum depth and interval was considered as a benchmark to set ten irrigation regime treatments including farmers practice. A split-plot design with three replications was used at which water depth assigned as main plot and interval as subplot treatments. The depth of irrigation was fixed at $\left(\mathrm{I}_{3}\right),\left(\mathrm{I}_{2}\right)$, and $\left(I_{1}\right)$ of optimum CROPWAT generated depth and irrigation interval of (5), (7), and (9) days (Table 1). The hand held watering cane was used to control the amount of water entering each furrow with the experimental plot (Yihun, 2015). 


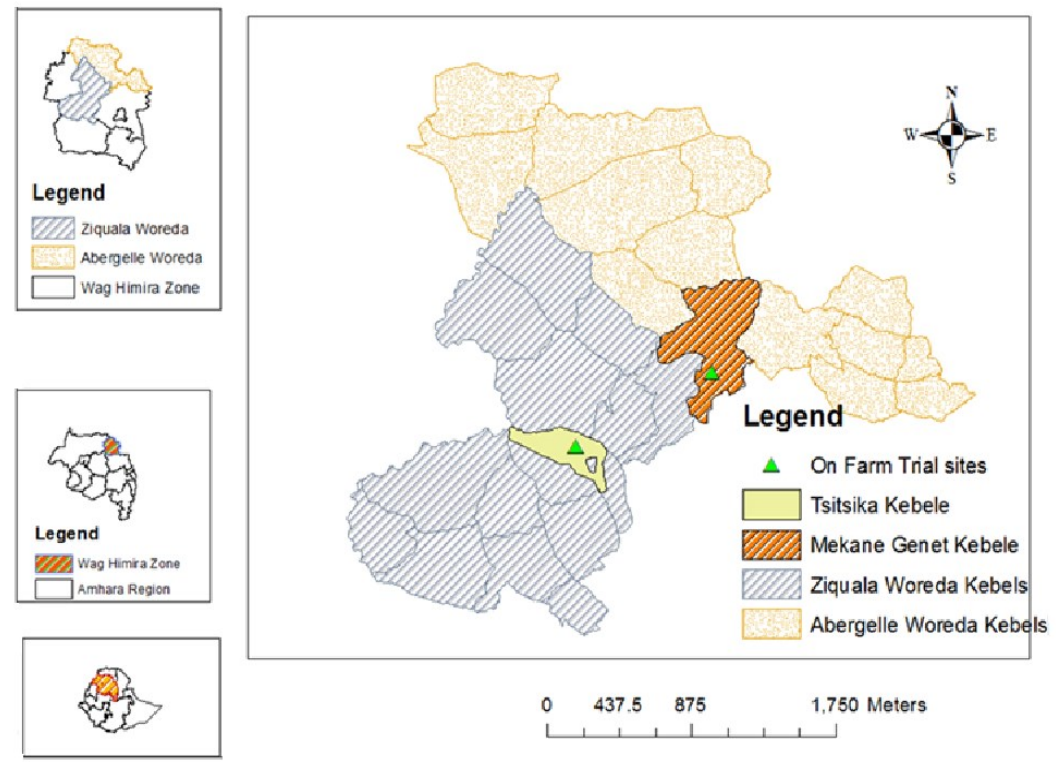

Figure1. Location map of study area in Amhara Region, Ethiopia.

Table 1. CROPWAT fixed application depth and optimal time of application on amount of applied water (mm) treatments in the experimental area.

\begin{tabular}{|c|c|c|}
\hline \multirow{2}{*}{ Treatments } & \multicolumn{2}{|c|}{ Amount of applied water $(\mathrm{mm})$} \\
\hline & Ziqualla & Abergelle \\
\hline $125 \%\left(I_{3}\right)$ CROPWAT fixed depth ( and optimal time of application at 5-day interval & 455.3 & 445.7 \\
\hline $125 \%\left(I_{3}\right)$ CROPWAT fixed depth and optimal time of application at 7-day interval & 406.9 & 397.2 \\
\hline 125\% $\left(I_{3}\right)$ CROPWAT fixed depth and optimal time of application at 9-day interval & 343.2 & 338.1 \\
\hline $100 \%\left(\mathrm{I}_{2}\right)$ CROPWAT fixed depth and optimal time of application at 5-day interval & 288.2 & 295.3 \\
\hline $100 \%\left(I_{2}\right)$ CROPWAT fixed depth and optimal time of application at 7-day interval & 284.8 & 279.4 \\
\hline $100 \%\left(I_{2}\right)$ CROPWAT fixed depth and optimal time of application at 9-day interval & 251.1 & 247.9 \\
\hline 75\% $\left(\mathrm{I}_{1}\right)$ CROPWAT fixed depth and optimal time of application at 5-day interval & 225.7 & 229.1 \\
\hline 75\% $\left(I_{1}\right)$ CROPWAT fixed depth and optimal time of application at 7-day interval & 233.9 & 240.7 \\
\hline 75\% $\left(I_{1}\right)$ CROPWAT fixed depth and optimal time of application at 9-day interval & 222.9 & 218.2 \\
\hline Farmer's practice irrigation depth (Fd) and irrigation interval in days (Ff) & 728.5 & 796.5 \\
\hline
\end{tabular}

Determination of reference evapotranspiration

The reference evapotranspiration (ETo) on daily basis was calculated by applying the modified FAO Penman-Monteith equation based on daily record of climatic data (Allen et al., 1998) using FAO CROPWAT software version 8.0. The input data for the CROPWAT software includes location i.e. altitude, latitude, and longitude of the meteorological station, daily values of maximum and minimum air temperatures, air humidity, sunshine duration, and wind speed were used from the nearest meteorological station located on the experimental field.

\section{Determination of crop water requirement using CROPWAT}

The amount of water needed (CWR) to compensate the amount of water lost through evapotranspiration (ETc), requires reference evapotranspiration (ETo) and hot pepper crop coefficient (Kc) given by (Allen et al., 1998) as 0.5 for the initial stage, $0.5<\mathrm{Kc}<1.15$ for the crop development stage, 1.15 for the mid-season stage and 0.6 for the late season stage. Calculation of crop water requirement (ETc) using CROPWAT software over the growing season was from ETo and crop coefficient (Kc).

$\mathrm{ETc}=\mathrm{ETo}^{*} \mathrm{Kc}$
Where, $E T c=$ actual evapotranspiration (mm/day), $\mathrm{Kc}=\mathrm{crop}$ coefficient, and ETo = reference crop evapotranspiration ( $\mathrm{mm} /$ day). The net irrigation requirement was calculated using the CROPWAT software based on (Allen et al., 1998) as follows:

$\mathrm{IRn}=\mathrm{ETC}-\mathrm{Pe}$

Where, $I R n=$ Net irrigation requirement $(\mathrm{mm}), \mathrm{ETc}$ in $\mathrm{mm}$ and $\mathrm{Pe}$ = effective rainfall $(\mathrm{mm})$ which is part of the rainfall that enters into the soil and makes available for crop production. The effective rainfall (pe) was estimated using the method given by (Allen et al., 1998) as.

$\mathrm{Pe}=0.6 * \mathrm{P}-10 / 3$ for $\mathrm{P}$ month $<=70 \mathrm{~mm}$ or

$\mathrm{Pe}=0.8^{*} \mathrm{P}-24 / 3$ for $\mathrm{P}$ month $>70 \mathrm{~mm}$

Where, $\mathrm{Pe}(\mathrm{mm})=$ effective rainfall and $\mathrm{P}(\mathrm{mm})=$ total rain fall.

The gross irrigation requirements account for losses of water incurred during conveyance and application to the field. This is expressed in terms of efficiencies when calculating project gross irrigation requirements from net irrigation requirements, as shown below: 
$\mathrm{IRg}=\mathrm{IRn} / \mathrm{Ea}$

Eq. (5)

Where, $\mathrm{IRg}=$ gross irrigation requirement $(\mathrm{mm})$

Ea= irrigation efficiency

Composite soil samples were collected from field plots and the soil textural analysis was done by hydrometer soil analysis method and soil textural class was determined from soil textural triangle. Field capacity, permanent wilting point, and moisture at saturation were determined using Pressure plate apparatus from laboratory analysis of soil samples. Total Available Moisture in the soil for the crop during the growing season was calculated as field capacity minus wilting point times the rooting depth of the crop.

Readily Available Moisture (RAM) was calculated as TAM*P, Where $P$ is the depletion fraction as defined by the crop coefficient $(\mathrm{Kc})$ files. Water productivity, also known as water use efficiency, was determined as the ratio of crop yield per unit area, in terms of grain, to crop evapotranspiration ( $\mathrm{mm}$ ), and was expressed as $\mathrm{kg}$ of grain or biomass per $\mathrm{m}^{3}$ of consumed water.

$$
\text { Water productivity }\left(\frac{\mathrm{kg}}{\mathrm{m} 3}\right)=\frac{\text { Total yield of green pepper }}{\text { water delivered up to harvesting }}
$$

\section{Data analysis}

All the agronomic data like plant height, pod length, pod diameter, canopy diameter, yield and water productivity were recorded and being subjected to analysis. Analysis of variance and correlation was performed using SAS Statistical Software Version 9.1. Effects were considered significant in all statistical calculations if the P-values were $\leq 0.05$. Means were separated using Fisher's Least Significant Difference (LSD) test.

\section{RESULTS AND DISCUSSION}

An interaction effect of depth and frequency on marketable yield, total yield, and water productivity on Ziqualla (Table 2). The result revealed that $I_{1}$ and $I_{2}$ CROPWAT generated depth using 5 and 7 days irrigation interval improved marketable yield, total yield and water productivity of hot pepper (C. annum) crop production, respectively. But farmers' irrigation scheduling and depth application practices are low yield gain because of more apply water and some of gap irrigation intervals cause water logging, plants are not freely aired. In general, $I_{1}$ CROPWAT generated depth at 5 days irrigation interval provided a better yield and yield related components. The result in agreement with the finding of (Khalkho et al., 2013) reported that yield and growth parameter data shown that the crop receiving irrigation at $60 \%$ available soil moisture offered the maximum green hot pepper yield of 9.1ton/ha (Yang et al., 2017) stated that water deficit from reducing irrigation amounts to $1 / 3$ to $2 / 3$ of full irrigation during the development and middle stages did not affect pepper yield; compared with full irrigation, the water deficit even increased fruit yields. These results occurred mainly because the water content under deficit irrigation in the study by (Yang et al., 2017) still reached higher than $70 \%$ of FC, which is sufficient for pepper growth (Liu et al., 2012). At the same time, full irrigation with a water content of $100 \%$ of FC in their study is very high and can reduce pepper yields (Liu et al., 2012). This study could be used for irrigating an additional land of 0.28 ha. The finding in line with (Serna Perez and Zegbe, 2012) described that hot pepper study, a water deficit of $15-45 \%$ can conserve 8$30 \%$ of irrigation water, and compared with full irrigation, a water deficit of $60 \%$ produced the highest percentage of marketable fruit but at similar yields as those under full irrigation in 2 of 3 years, consequently increasing irrigation water productivity. Associated with full irrigation, deficit irrigation can reduce irrigation depths by $20-50 \%$ and ultimately result in a higher water productivity (Dorji et al., 2005, Gençoğlan et al., 2006, Gonzalez-Dugo et al., 2007, Yang et al., 2018, Al-Ghobari and Dewidar, 2018; Abayomi et al., 2012). Moreover, those studies $I_{1}$ CROPWAT generated depth application at 5 days irrigation interval as compared to farmer's practice, irrigation scheduling and application depth saved $5028 \mathrm{~m}^{3} /$ ha amount of irrigation water. This amount of irrigation water could be used to irrigate an additional irrigation land of 2.2ha with a yield benefit of 25.2 ton/ha of hot pepper (C. annum) crop production.

While observing variations among treatments, the only variation for the experiment was water application depth and time of application among treatments throughout the hot pepper growth stage. The variation in water amount applied each irrigation was attributed to the $K_{c}$ value variations in the stages of crop growth. As it is observed from the experiment, crop water requirement was low at the initial stage, increased during the development stage, reached a maximum at the mid-season stage, and declined during the late-season stage.

Table 2. Interaction effects of depth and frequency on marketable yield, total yield, and water productivity in Ziqualla.

\begin{tabular}{|c|c|c|c|c|c|c|c|c|c|c|c|c|}
\hline \multirow{3}{*}{ Frequency } & \multicolumn{4}{|c|}{ Total yield (ton/ha) } & \multicolumn{4}{|c|}{ Marketable yield (ton/ha) } & \multicolumn{4}{|c|}{ Water productivity $\left(\mathrm{kg} / \mathrm{m}^{3}\right)$} \\
\hline & \multicolumn{4}{|c|}{ Depth } & \multicolumn{4}{|c|}{ Depth } & \multicolumn{4}{|c|}{ Depth } \\
\hline & $I_{1}$ & $\mathrm{I}_{2}$ & $I_{3}$ & $F_{d}$ & $I_{1}$ & $\mathrm{I}_{2}$ & $I_{3}$ & $F_{\mathrm{d}}$ & I1 & $\mathrm{I}_{2}$ & $I_{3}$ & $F_{d}$ \\
\hline 5 days & 11.5 & 9.3 & 9.2 & & 11.2 & 9.0 & 8.9 & & 5.06 & 3.85 & 2.63 & \\
\hline 7 days & 9.1 & 11.6 & 9.1 & & 8.8 & 11.3 & 8.8 & & 2.86 & 4.55 & 2.87 & \\
\hline 9 days & 3.1 & 3.1 & 3.4 & & 2.8 & 2.7 & 3.1 & & 1.82 & 1.56 & 1.33 & \\
\hline $\mathrm{Ff}$ & & & & 5.7 & & & & 5.4 & & & & 1.64 \\
\hline LSD & 0.9 & & & & 1.0 & & & & 0.57 & & & \\
\hline $\mathrm{Cv}(\%)$ & 10.09 & & & & 10.13 & & & & 15.21 & & & \\
\hline
\end{tabular}

Where, $I_{1}=75 \%$ crop water requirement, $I_{2}=100 \%$ crop water requirement, $I_{3}=125 \%$ crop water requirement, $F_{d}=$ farmer practice irrigation depth, $\mathrm{F}_{\mathrm{f}}=$ farmer practice irrigation interval. 
Table 3. Effects of depth and frequency on pod length, pod diameter, no. of pod per plant, plant height, canopy diameter and unmarketable yield at Ziqualla experimental site.

\begin{tabular}{|c|c|c|c|c|c|c|}
\hline Treatment & $\begin{array}{l}\text { Pod length } \\
\text { (cm) }\end{array}$ & $\begin{array}{l}\text { Pod diameter } \\
(\mathrm{cm})\end{array}$ & $\begin{array}{l}\text { No. of pod } \\
\text { per plant }\end{array}$ & $\begin{array}{c}\text { Plant } \\
\text { height }(\mathrm{cm})\end{array}$ & $\begin{array}{c}\text { Canopy diameter } \\
(\mathrm{cm})\end{array}$ & $\begin{array}{l}\text { Unmarketable } \\
\text { yield (ton/ha) }\end{array}$ \\
\hline \multicolumn{7}{|l|}{ Depth } \\
\hline $\mathrm{I}_{1}$ & $9.06 a$ & $1.47 a$ & 18.78a & $71.33 a$ & $39.34 a$ & $0.24 a$ \\
\hline $\mathrm{I}_{2}$ & $8.80 a$ & $1.45 a$ & $20.15 a$ & $70.62 a$ & $38.97 a$ & $0.27 a$ \\
\hline$I_{3}$ & $8.92 a$ & $1.41 a$ & $19.65 a$ & 69.07a & 38.01ab & $0.26 a$ \\
\hline $\mathrm{Fp}$ & $6.42 b$ & $1.18 b$ & $13.96 b$ & $64.30 \mathrm{a}$ & $34.56 b$ & $0.27 a$ \\
\hline LSD & 1.97 & 0.19 & 3.15 & 9.95 & 3.67 & 0.09 \\
\hline Cv (\%) & 17.09 & 10.57 & 12.47 & 10.71 & 7.18 & 27.14 \\
\hline \multicolumn{7}{|l|}{ Frequency } \\
\hline 5 days & $9.40 a$ & $1.51 \mathrm{a}$ & $23.85 a$ & $76.32 \mathrm{a}$ & $42.28 a$ & $0.25 a$ \\
\hline 7 days & $8.96 a$ & $1.45 a$ & $22.36 a$ & 71.82ab & $42.44 a$ & $0.24 a$ \\
\hline 9 days & $8.42 a$ & 1.37ab & $12.37 b$ & $62.90 \mathrm{~b}$ & $31.60 b$ & $0.27 a$ \\
\hline $\mathrm{F}_{\mathrm{p}}$ & $6.42 b$ & $1.18 b$ & $13.96 b$ & $64.30 \mathrm{~b}$ & $34.56 b$ & $0.29 a$ \\
\hline LSD & 1.97 & 0.19 & 3.15 & 9.95 & 3.67 & 0.09 \\
\hline Cv (\%) & 17.09 & 10.57 & 12.47 & 10.71 & 7.18 & 27.14 \\
\hline
\end{tabular}

Table 4. Correlation coefficient of the different parameter (number of pod per plant, marketable yield, unmarketable yield, total yield, and water productivity) from the study data.

\begin{tabular}{lccccc}
\hline Parameters & $\begin{array}{c}\text { Number of pod per } \\
\text { plant }\end{array}$ & $\begin{array}{c}\text { Marketable } \\
\text { yield }\end{array}$ & $\begin{array}{c}\text { Unmarketable } \\
\text { yield }\end{array}$ & Total yield & Water productivity \\
\hline Number of pod per plant & 1 & & & & \\
Marketable yield & $0.93^{* * *}$ & 1 & & & \\
Unmarketable yield & $-0.11 \mathrm{~ns}$ & $-0.15 \mathrm{~ns}$ & 1 & 1 & \\
Total yield & $0.93^{* * *}$ & $0.99^{* * *}$ & $-0.12 \mathrm{~ns}$ & 1 & 1 \\
Water productivity & $0.84^{* *}$ & $0.90^{* * *}$ & $-0.13 \mathrm{~ns}$ & $0.90^{* * *}$ & 1 \\
\hline
\end{tabular}

$(P \leq 0.05){ }^{* * *}$ Very highly significant, ${ }^{* *}$ Very significant, ${ }^{*}$ significant, ${ }^{\text {ns }}$ none significant

Table 5. The interaction effects of depth and frequency on number of pod per plant, total yield, marketable yield and water productivity in Abergelle experimental site.

\begin{tabular}{|c|c|c|c|c|c|c|c|c|c|c|c|c|c|c|c|c|}
\hline \multirow{3}{*}{ Frequency } & \multicolumn{4}{|c|}{ No. of pod per plant } & \multicolumn{4}{|c|}{ Total yield (ton/ha) } & \multicolumn{4}{|c|}{ Marketable yield (ton/ha) } & \multicolumn{4}{|c|}{ Water productivity $\left(\mathrm{kg} / \mathrm{m}^{3}\right)$} \\
\hline & \multicolumn{4}{|c|}{ Depth } & \multicolumn{4}{|c|}{ Depth } & \multicolumn{4}{|c|}{ Depth } & \multicolumn{4}{|c|}{ Depth } \\
\hline & $I_{1}$ & $I_{2}$ & $I_{3}$ & $F_{d}$ & $I_{1}$ & $I_{2}$ & $I_{3}$ & $F_{d}$ & $I_{1}$ & $\mathrm{I}_{2}$ & $I_{3}$ & $F_{d}$ & $I_{1}$ & $I_{2}$ & $I_{3}$ & $F_{d}$ \\
\hline 5 days & 19.6 & 17.6 & 17.3 & & 9.2 & 8.0 & 7.6 & & 8.8 & 7.8 & 7.2 & & 4.10 & 3.14 & 2.00 & \\
\hline 7 days & 13.9 & 20.0 & 18.7 & & 7.8 & 8.9 & 7.9 & & 7.5 & 8.6 & 7.5 & & 2.92 & 4.09 & 2.73 & \\
\hline 9 days & 10.4 & 12.9 & 14.4 & & 3.0 & 2.8 & 3.0 & & 2.6 & 2.5 & 2.7 & & 1.91 & 1.29 & 1.19 & \\
\hline $\mathrm{Ff}$ & & & & 13.0 & & & & 6.0 & & & & 5.7 & & & & 0.88 \\
\hline LSD & 2.30 & & & & 0.7 & & & & 0.7 & & & & 0.35 & & & \\
\hline Cv (\%) & 10.96 & & & & 8.35 & & & & 8.89 & & & & 10.97 & & & \\
\hline
\end{tabular}

Where, $I_{1}=75 \%$ crop water requirement, $I_{2}=100 \%$ crop water requirement, $I_{3}=125 \%$ crop water requirement, $F_{d}=$ Farmer practice irrigation depth, $\mathrm{F}+=$ Farmer practice irrigation interval.

There were non-interaction effects in both depth and frequency on pod length, pod diameter, number of pod per plant, plant height, canopy diameter and the unmarketable yield on Ziqualla experimental site (Table 3 ). The optimum application of $I_{1}, I_{2}$, CROPWAT generated depth had better pod length, pod diameter and a number of pod per plant compared with irrigation application of farmers' practice. Considering the interval of the irrigation application, statistically, there was non-significance difference in terms of pod length, pod diameter, number of pod per plant, canopy diameter and unmarketable yield for 5 and 7 days interval. For instance, the farmer's irrigation practices contributed to the lowest pod length of $6.42 \mathrm{~cm}$ whereas irrigation application with 5,7 , days irrigation interval had $9.4,8.96 \mathrm{~cm}$, respectively. This result in line with (Delelegn, 2011) informed that hot pepper which obtained a better pod diameter and pod length using Mareko Fana at Jimma areas. Larger and wider hot pepper pods are considered to be the best in quality and have better demand for fresh as well as dry pod use in Ethiopian markets (Beyene and David, 2007). It can be taken as a suggested $I_{1}$ CROPWAT generated depth and irrigation application of 5 days irrigation interval offered the highest value for the yield and yield related parameters of Ziqualla experimental site (Table 2). The result indicated that the variability of the amount of water application and irrigation interval has a significant effect on yield and yield correlated component for hot pepper (C. annum).

Correlation analysis between yield parameters was tested using ttest as shown in Table 4. The result revealed a highly correlation coefficient $(r \geq 0.9)$ of marketable yield with a number of pod per plant, total yield, and water productivity. Similarly, water productivity had also a highly significant correlation $(r \geq 0.8)$ with the number of pod per plant. However, unmarketable yield was negatively correlated with other parameters at $P<0.05$ probability (Table 4 ). 
There was an interaction effect both in depth and irrigation frequency on a number of pods per plant, marketable yield, total yield, and water productivity in a situation of Abergelle (Table 5). The effect indicated that irrigation application of $I_{1}$ and $I_{2}$ CROPWAT generated depth with 5 and 7 days irrigation intervals were recorded the highest pods per plant, marketable yield, total yield, and water productivity, respectively. These results were statistically significant pods per plant, marketable yield, total yield, water productivity compared with other treatments. They had a yield enhancement of 3.1ton/ha and 2.8ton/ha in that order related to the farmer's irrigation application practices. In relationships of water productivity, irrigation application of CROPWAT generated depth $I_{1}$ and $I_{2}$ with 5 days irrigation interval, about $662 \mathrm{~m}^{3} /$ ha amount of irrigation water was saved which would like to irrigate an additional lands of 0.29 ha that produce 2.6 ton/ha. The yield variance between the two application depths was 3.7ton/ha of hot pepper (C. annum) crop yield advantages by using $\mathrm{I}_{1}$ CROPWAT generated depth. In the same way, as compared to farmer irrigation practices, $5675 \mathrm{~m}^{3} / \mathrm{ha}$ amount of irrigation water, which could confine to irrigate another land of 2.4ha that produces 22.1ton/ha yield gain of hot pepper production in Abergelle areas.
In irrigation studies, Zegbe-Dominguez et al. (2004) and Kang et al. (2001) reported that for optimum irrigation scheduling, sound knowledge of the soil-water status, crop water requirements, crop stress status, potential yield reduction if the crops remain in stressed condition is required to maximize yield and optimizes water productivity.

Not at all interaction effects in both depth and frequency on pod length, pod diameter, plant height, canopy diameter and unmarketable yield of a hot pepper crops trendy instance of Abergelle. Since, irrigation interval point of view, the table exhibited that there were the non-significance difference between irrigation application of 5 and 7 days in terms of pod length, pod diameter, plant height, and canopy diameter.

The correlation coefficient analysis such as indicated that marketable yield was significantly correlated $(r \geq 0.9)$ with total yield, and also water productivity was significantly correlated through marketable yield and total yield $(r \geq 0.8)$, but negatively correlated with unmarketable yield (Table 7). The t-test analysis for correlation coefficient with 95\% confidence interval showed that there was a significant difference in all the parameters except unmarketable yield.

Table 6. Effects of depth and frequency on pod length, pod diameter, plant height, canopy diameter and the unmarketable yield of hot pepper (C. annum) in Abergelle.

\begin{tabular}{|c|c|c|c|c|c|}
\hline Treatment & $\begin{array}{l}\text { Pod length } \\
(\mathrm{cm})\end{array}$ & $\begin{array}{l}\text { Pod diameter } \\
\qquad(\mathrm{cm})\end{array}$ & $\begin{array}{l}\text { Plant height } \\
(\mathrm{cm})\end{array}$ & $\begin{array}{l}\text { Canopy diameter } \\
(\mathrm{cm})\end{array}$ & $\begin{array}{l}\text { Unmarketable } \\
\text { yield (ton/ha) }\end{array}$ \\
\hline \multicolumn{6}{|l|}{ Depth } \\
\hline $\mathrm{I}_{1}$ & $8.41 a$ & $0.80 a b$ & $69.90 a$ & $39.48 a$ & $0.31 \mathrm{ab}$ \\
\hline $\mathrm{I}_{2}$ & $8.21 a$ & $0.85 a$ & $69.02 a$ & 37.91ab & $0.25 b$ \\
\hline $\mathrm{I}_{3}$ & $8.24 a$ & $0.86 a$ & $68.95 a$ & 38.05ab & $0.34 a$ \\
\hline$F_{d}$ & $7.41 a$ & $0.65 b$ & $68.00 a$ & $32.26 \mathrm{~b}$ & $0.33 a b$ \\
\hline LSD & 1.67 & 0.15 & 9.66 & 6.90 & 0.08 \\
\hline Cv (\%) & 15.28 & 13.94 & 10.49 & 13.68 & 19.72 \\
\hline \multicolumn{6}{|l|}{ Frequency } \\
\hline 5 days & $9.46 a$ & $0.93 a$ & $72.22 \mathrm{a}$ & $41.82 \mathrm{a}$ & $0.35 a$ \\
\hline 7 days & 8.83ab & $0.90 a$ & $70.87 a$ & $41.65 a$ & $0.27 b$ \\
\hline 9 days & $6.58 c$ & $0.67 b$ & $64.77 a$ & $31.97 b$ & $0.28 a b$ \\
\hline$F_{f}$ & $7.41 b c$ & $0.65 b$ & $68.00 \mathrm{a}$ & $32.26 \mathrm{~b}$ & $0.33 a b$ \\
\hline LSD & 1.67 & 0.15 & 9.66 & 6.90 & 0.08 \\
\hline Cv (\%) & 15.28 & 13.94 & 10.49 & 13.68 & 19.72 \\
\hline
\end{tabular}

Table 7. Correlation coefficient of different parameters (number of pod per plant, marketable yield, unmarketable yield, total yield, and water productivity) from the study data.

\begin{tabular}{|c|c|c|c|c|c|}
\hline Parameters & $\begin{array}{l}\text { Number of pod per } \\
\text { plant }\end{array}$ & $\begin{array}{c}\text { Marketable } \\
\text { yield }\end{array}$ & $\begin{array}{c}\text { Unmarketable } \\
\text { yield }\end{array}$ & Total yield & Water productivity \\
\hline Number of pod per plant & 1 & & & & \\
\hline Marketable yield & $0.78^{*}$ & 1 & & & \\
\hline Unmarketable yield & $0.04 \mathrm{~ns}$ & $0.09 \mathrm{~ns}$ & 1 & & \\
\hline Total yield & $0.78^{*}$ & $0.99^{* * *}$ & $0.12 \mathrm{~ns}$ & 1 & \\
\hline Water productivity & $0.73^{*}$ & $0.81^{* *}$ & $-0.08 n s$ & $0.80^{* *}$ & 1 \\
\hline
\end{tabular}

$(P \leq 0.05)^{* * *}$ Very highly significant, ${ }^{* *}$ Very significant, ${ }^{*}$ significant, ${ }^{\text {ns }}$ none significant 
Conclusion

The results of the experiment was conducted at Ziqualla, Tsitsika small-scale irrigation scheme, and Abergelle, Bahir smallscale irrigation scheme showed that research intervention was very important for improving crop production of hot pepper (C. annum) by saving a significant amount of water for irrigating the additional land. Application of irrigation depth at specific irrigation interval has shown a significant effect on yield and water productivity when compared with farmers' irrigating practices. Irrigation application of $\mathrm{I}_{1}$ and $\mathrm{I}_{2}$ CROPWAT generated depth at 5 and 7 days irrigation interval provided a relatively significant and higher value in terms of many yield parameters including marketable yield and water productivity both on Ziqualla and Abergelle. Comparing with farmers' practice, $I_{1}$ CROPWAT generated depth at 5 days irrigation intervals saved irrigation water that would irrigate an additional land of about 2.2ha on Ziqualla, 2.4ha, on Abergelle. However, considering the economic advantage of water productivity between $I_{1}$ CROPWAT generated depth at 5 days irrigation interval and $\mathrm{I}_{1}$ CROPWAT generated depth at 7 days irrigation interval, $I_{1}$ depth at 5 days interval had a relatively higher yield advantage of 7.8 ton/ha and 6.1ton/ha on Ziqualla and Abergelle, respectively. The main agricultural water management strategy for dry land and water scarcity areas like Wag-himra is primarily to improve the agricultural productivity and hence the income of the farmers by applying optimum amount of water and saving a significant amount of water for irrigation additional hot pepper crop land. Considering this, the irrigation application of $\mathrm{I}_{1}$ CROPWAT generated depth at 5 days irrigation interval was found economically feasible. Accordingly, it is recommended to be used by the farmers and other water users in Ziqualla and Abergelle woreda and other similar agro-ecological zones. Furthermore, further research on fertilizer rate for hot pepper under irrigation is suggested.

\section{ACKNOWLEDGEMENT}

The authors would like to thank the Amhara Agricultural Research Institute and Sekota Dry-Land Agricultural Research Center for funding finance. I also appreciate colleagues in soil and water management directorate for their assistance in data collection and field management.

Open Access: This is an open access article distributed under the terms of the Creative Commons Attribution 4.0 License, which permits unrestricted use, distribution, and reproduction in any medium, provided the original author(s) if the sources are credited.

\section{REFERENCES}

Abayomi, Y., Aduloju, M., Egbewunmi, M. and Suleiman, B. (2012). Effects of soil moisture contents and rates of NPK fertilizer application on growth and fruit yields of pepper (Capsicum spp.) genotypes. International Journal of AgriScience, 2: 651-663, http://agris.fao.org/agris-search/search.do recor-
Al-Ghobari, H.M. and Dewidar, A.Z. (2018). Integrating deficit irrigation into surface and subsurface drip irrigation as a strategy to save water in arid regions. Agricultural Water Management, 209:

55-61, https://doi.org/10.1016/j.agwat.2018.07.010

Allen, R.G., Pereira, L.S., Raes, D. and Smith, M. (1998). Crop evapotranspiration: guidelines for computing crop requirements. FAO Irrigation and Drainage Paper No. 56. FAO, Rome, Italy

Alvino, A., Centritto, M. and Lorenzi, F.D. (1994). Photosynthesis response of sunlit and shade pepper (Capsicum annuum) leaves at different positions in the canopy under two water regimes. Australian Journal of Plant Physiology, 21: 377-391, http://agris.fao.org/agris-search/search.do? recordID=AU19950065390

Beyene T. and David, P. (2007). Ensuring Small Scale Producers in Ethiopia to Achieve Sustainable and Fair Access to Pepper Market. Uganda Journal of Agriculture, 3(2): 113-119.

Bossie, M., Tilahun, K. and Hordofa, T. (2009). Crop coefficient and evaptranspiration of onion at Awash Melkassa, Central Rift Valley of Ethiopia. Irrigation and Drainage Systems, 23 (1): 1-10, https://doi.org/10.1007/s10795-009-9059-9

Delelegn, S. (2011). Evaluation of Elite Hot Pepper Varieties (Capsicum species) for growth, dry pod yield and quality under Jimma condition, South West Ethiopia. Jimma University.

Delfine, S., Tognetti, R., Loreto, F. and Alvino, A. (2015). Physiological and growth responses to water stress in Field-grown bell pepper (Capsicum annuum L.). The Journal of Horticultural Science and Biotechnology, 77(6): 697-704, https://doi.org/10.1080/14620316.2002.11511559

Dorji, K., Behboudian, M. and Zegbe-Dominguez, J. (2005). Water relations, growth, yield, and fruit quality of hot pepper under deficit irrigation and partial rootzone drying. Scientia Horticulturae, 104: 137-149, https://doi.org/10.1016/j.scienta.2004.08.015

EIAR (2004). Sustainable Highland Rivers Management LARIMA (Land \& river Management). Ethiopian Institute of Agricultural Research, Addis Ababa, Ethiopia. Retrieved on December 2018 from: http://www.eiar.gov.et/about-eiar

FAO (2017). FAOSTAT online statistical service. Food and Agriculture Organization of the United Nations (FAO), Ethopia. Available via URL. http://www.fao.org/faostat/en/ \#country/238. Accessed December, 2018.

Gençoğlan, C., Akinci, İ. E., Uçan, K., Akinci, S. \& Gençoğlan, S. (2006). Response of red hot pepper plant (Capsicum annuum L.) to the deficit irrigation. Mediterranean Agricultural Sciences, 19: 131-138, http://ziraatdergi.akdeniz.edu.tr/_dinamik/144/214.pdf

Gonzalez-Dugo, V., Orgaz, F. and Fereres, E. (2007). Responses of pepper to deficit irrigation for paprika production. Scientia Horticulturae, 114: 77-82, https://doi.org/10.1016/j.scienta.2007.05.014

Kang, S., Zhang, L., Hu, X., Li, Z. and Jerie, P. (2001). An improved water use efficiency for hot pepper grown under controlled 
alternate drip irrigation on partial roots. Scientia Horticulturae, 89: 257-267, https://doi.org/10.1016/S0304-4238(00)00245-4

Khalkho, D., Naik, R., Thakur, A. and Bisen, Y. (2013). Effective irrigation water management in Rabi Chilli for Bastar agro climatic zone. Scientific Research and Essays, 8: 2332-2335, https://doi.org/10.5897/SRE2013.5686

Kirda, C. (2002). Deficit irrigation scheduling based on plant growth stages showing water stress tolerance. Food and Agricultural Organization of the United Nations, Deficit Irrigation Practices, Water Reports, 22: 102.

Kulkarni, M. and Phalke, S. (2009). Evaluating variability of root size system and its constitutive traits in hot pepper (Capsicum annum L.) under water stress. Scientia Horticulturae, 120: 159-166, https://doi.org/10.1016/j.scienta.2008.10.007

Liu, H., Yang, H., Zheng, J., Jia, D., Wang, J., Li, Y. and Huang, G. (2012). Irrigation scheduling strategies based on soil matric potential on yield and fruit quality of mulched-drip irrigated chili pepper in northwest China. Agricultural water management, 115: 232-241, https://doi.org/10.1016/j.agwat.2012.09.009

Mazourek, M., Pujar, A., Borovsky, Y., Paran, I., Mueller, L. and Jahn, M.M. (2009). A dynamic interface for capsaicinoid systems biology. Plant Physiology, 150: 1806-1821, https://doi.org/10.1104/pp.109.136549

Nalla, M. K., Sharma, V., Mangal, M., Srivastava, A., Raje, R., Dey, S. and Chandel, C. (2017). Assessment of environmental effect on fertility restoration in sweet pepper (Capsicum annum L. var. grossum). International Journal of Current Microbiology and Applied Sciences, 6: 870-877, https://doi.org/10.20546/ijcmas.2017.612.094

Roukens, O., Tadele, W. and Tamrat, K. (2005). Export potential of Ethiopian oleoresins. Ethiopian Export Promotion Department, 7-14.

Serna Perez, A. and Zegbe, J. A. (2012). Yield, fruit quality and water use efficiency of chili'mirasol'under irrigation deficit. Revista Fitotecnia Mexicana, 35: 53-56.

Tyagi, N.K., Sharma, D.K. and Luthra, S.K. (2000). Determination of evapotranspiration and crop coefficients of rice and sunflower with lysimeter. Agricultural Water Management, 45(1): 41-54, https://doi.org/10.1016/S0378-3774(99)00071-2

Valipour, M. (2015). Land use policy and agricultural water management of the previous half of century in Africa. Applied Water Science, 5: 367-395, https://doi.org/10.1007/s13201-014-0199-1

Yang, H., Du, T., Qiu, R., Chen, J., Wang, F., Li, Y., Wang, C., Gao, L. and Kang, S. (2017). Improved water use efficiency and fruit quality of greenhouse crops under regulated deficit irrigation in northwest China. Agricultural Water Management, 179: 193-204, https://doi.org/10.1016/j.agwat.2016.05.029

Yang, H., Liu, H., Zheng, J. and Huang, Q. (2018). Effects of regulated deficit irrigation on yield and water productivity of chili pepper (Capsicum annuum L.) in the arid environment of northwest China. Irrigation Science, 36: 61-74, https://doi.org/10.1007/s00271-017-0566-4

Yihun, Y.M. (2015). Agricultural water productivity optimization for irrigated Teff (Eragrostic Tef) in water scarce semi-arid region of Ethiopia Agricultural water productivity optimization for irrigated Teff (Eragrostic Tef) in water scarce semiarid region of Ethiopia, CRC Press/Balkema.

Zegbe-Dominguez, J., Behboudian, M., Lang, A. and Clothier, B. (2004). Water relations, growth, and yield of processing tomatoes under partial rootzone drying. Journal of Vegetable Crop Production, 9: 31-40, https://doi.org/10.1300/J068v09n02_05 